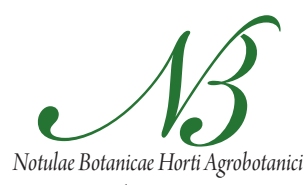

Cluj-Napoca

\title{
The Checklist of the Sardinian Alien Flora: an Update
}

\author{
Lina PODDA ${ }^{1}$, Valerio LAZZERI², Francesco MASCIA², Olga \\ MAYORAL ${ }^{3 *}$, Gianluigi BACCHETTA² \\ ${ }^{1}$ CRITERIA S.r.l.via Cugia 14,09129 - Cagliari, Italy; l.podda@criteriaweb.it \\ ${ }^{2}$ Università degli Studi di Cagliari, Centro Conservazione Biodiversità (CCB), Dipartimento di Scienze della \\ Vita e dell'Ambiente, v.le S. Ignazio da Laconi 13,09123-Cagliari, Italy; bacchet@unica.it \\ ${ }^{3}$ Universidad Politécnica de Valencia, IGIC, Dep. Ecosist. Agrofor., EPSG, Av. Paraninfo 1, 46730, Grao \\ de Gandia, Gandia-Valencia, Spain; olmagar@eaf.upv.es ( ${ }^{*}$ corresponding author)
}

\begin{abstract}
Alien plants colonization, due to the fast spreading of highly invasive taxa, is more and more a serious source of concerns for habitat and species conservation. Apart direct in situ intervention, it is of major importance to acquire the best and up to date knowledge about alien taxa that currently threaten the integrity of wild and valuable environments. In this light, here is presented the update to the checklist of alien vascular flora of the island of Sardinia (Italy) on the basis of the new findings, nomenclatural adjustments, and revision of diffusion status of alien taxa. The checklist at present, consists of 541 taxa ( 84 doubtful) which represent $17 \%$ of the whole flora of the island; 22 taxa are new to the island and 7 of them for Italy. Neophytes represent the majority of the whole alien flora (301, 66\% of the total) and, in confront to archaeophytes, gather nearly all invasive taxa $(54 \mathrm{vs} 4$ ). The new findings are all neophytes. Phanerophytes (42\%) are the most representative biological form and Americas represents the region that mostly contributes to the Sardinian alien flora (33\%). Further analysis highlights that, in terms of number of taxa, highly anthropically impacted environments such as synanthropic (36\%) and agricultural (23\%) are the eligible habitats for most of the alien species in Sardinia while coastal areas and wetlands, beyond hosting a lower number of taxa, are characterized by the relative highest number of invasives.
\end{abstract}

Keywords: alien taxa, conservation, islands, invasions, Mediterranean, Sardinia

\section{Introduction}

Alien flora has become an important component of wild flora and stands as a real challenge for environmental management in the future. As this phenomenon is evolving quickly, it is now considered to be one of the most significant threats to European flora (Lambdon et al., 2008a).

Indeed in Europe the total number of alien plants listed in the DAISIE database has reached the dramatic amount of 5789 (Lambdon et al., 2008a; Pyšek et al., 2009) with a more than threefold increase in confront to the 1568 taxa reported in Flora Europaea (Tutin et al., 1964-1980). Although part of this increase can be attributed to a continuing influx of alien flora to individual countries (Pyšek et al., 2003) and the continent as a whole, this phenomenon alone cannot explain the huge difference. In fact another important reason is the raising awareness of the issue of alien species and the increasing research intensity in the last decades (Pyšek et al., 2006). Among these, national checklists and their updates together with on-line databases are gaining in importance and are more useful than a floral work of the Flora Europaea kind (Lambdon et al., 2008a; Tutin et al., 1964-1980) to depict the status of alien plants diffusion in Europe where, at present, 6.2 new alien taxa capable of naturalization are arriving each year (Pyšek et al., 2009).

The inventory of alien flora of Italy lists 1023 non-native species and subspecies, which account 13,4\% of all the Italian flora (Celesti-Grapow et al., 2009), corresponding to an increase of $1.2 \%$ from the previous work of Viegi $e t$ al. (1974). These data appear even more severe considering the rise of the total number of taxa of the Italian checklist since then.

Before the present update, the alien flora of Sardinia represented the $18.8 \%$ of the total flora (Podda et al., 2010) that constituted more than a twofold increase in less than 20 years (9.2\% in Viegi, 1993). On this basis, it is obvious how the progress of invasive plants is becoming a major concern for native and threatened taxa protection.

Similarly, this phenomenon has been observed in other Mediterranean islands that share with Sardinia a similar Mediterranean climate such as that of the nearby islands of Corsica and the Balearic Archipelago where the alien flora has grown in richness of taxa. The finding of new 68 alien taxa in 11 years corresponds to an increase of $18.1 \%$ from the Corsican 1996 list (Jeanmonod et al., 2011; Natali and Jeanmonod, 1996) while Podda et al. (2010) reported 40 new alien taxa for the Balearic Archipelago in confront 
to the previous checklist (Moragues and Rita, 2005). This demonstrates how, apart the improved expertise in alien taxa recognition, insular areas, especially in the Mediterranean Basin, seem to be very prone to alien plant invasions (Sala et al., 2000).

For this reason, it is of essential importance to maintain up to date the Sardinian checklist of the alien flora on the basis of the investigations that occurred since the last reports (Podda et al., 2010, 2011).

In this work the checklist of the Sardinian alien flora is provided and discussed from a biological, ecological, chorological and historical point of view as updated according to the new findings and the nomenclatural changes.

\section{Materials and methods}

The basis for the current checklist is represented by the first checklist of the Sardinian alien flora (Bacchetta et al., 2009) and the relative updates provided in the subsequent works about the comparison with the Balearic Islands (Podda et al., 2010, 2011). The area of investigation comprises the whole Sardinian territory, that covers an approximate area of $24.089 \mathrm{~km}^{2}$, including about 300 minor islands.

Data relative to the Sardinian alien flora have been subjected to intense revision and integrated with new findings as a result of field activities during the last 3 years. Taxa in the checklist (Annex 1: published on the journal web site, as a supplementary file) and data concerning their entry or introduction before or after 1492/1500 A. D. (archaeophyte or neophyte), diffusion status (casual, naturalized or invasive) and ecology are arranged in alphabetical order and grouped into families. Moreover the biological form and the origin are also provided.

The status of invasiveness was determined and ordered on the basis of the criteria proposed by Richardson et al. (2000), elaborated by Pyšek et al. (2004), and reviewed according to Richardson and Pyšek (2006). Archaeophytes and neophytes, these latter including ephemorophytes in the sense of Holub and Jirásek (1967) and escapees from cultivation, were differentiated depending on their introduction before or after 1492/1500 A. D., respectively. Since it is still a matter of debate if some species can be considered native or not and, in this latter case, if they are archaeophytes or neophytes (Carlton, 1996; CelestiGrapow et al., 2010), for these taxa for which such doubts still persist, we have preferred the attribution to the status of doubtful (D).

New entries in the alien flora checklist are marked with one asterisk or two (for the plants reported in other authors' works) in Annex 1, while the relative data on the sites of finding (name, coordinates, altitude, habitat, diffusion status, thermotype and ombrotype, potential invasiveness as reported in literature and herbarium data) are listed in Tab. 1.
From a nomenclatural point of view and for the attribution of the taxa to the plant families it was followed the on-line databases of The Plant List website (2010) and of the Med-Checklist website (Euro+Med, 2006-onwards). Concerning the validity of the plant families it was followed what is reported in the Angiosperm Phylogeny Group III (Chase and Reveal, 2009; Stevens, 2001-onwards) while for gymnosperms and pteridophytes the works of Christenhusz et al. (2011a, 2011b). Finally, when available, dedicated taxonomic revisions have been taken into account.

Concerning the biological forms, Raunkiaer lifeform classification (Raunkiaer, 1934) was followed with the adjustments and the abbreviations reported in Pignatti (1982) while data on the areas of origin of the various taxa follow what reported by Bacchetta et al. (2009) or the relative literature.

The distribution of the taxa among the different habitats has been based on their frequency of occurrence as deduced from the specific literature and from field observation according to the following seven categories as proposed by Bacchetta et al. (2009): (1) synanthropic; (2) agricultural; (3) wetlands; (4) coastal; (5) riparian; (6) woodlands; (7) matorrals.

Taxa were also classified according to their intentional or not intentional anthropogenic introduction, and following the definitions proposed by the Convention on Biological Diversity (CBD) (Miller et al., 2006). Regarding introduction pathways, the categories proposed by Sanz Elorza et al. (2004) and Hulme et al. (2008b) were followed.

Cultivated, ornamental or forestry taxa that do not show any degree of spontaneization have not been taken into account in the present work.

Calculations have been made on the checklist except for those taxa that must still be considered doubtful regarding their historical entrance in Sardinia, those that have not been found for a long time and whose actual presence or geographic origin are still unclear.

\section{Results and discussion}

On the basis of the recent findings and the revision of herbarium specimens the Sardinian checklist of the alien flora now consists of 541 taxa representing the $17 \%$ of the whole Sardinian flora (Conti et al., 2005, 2007).

Regarding the additions to the Sardinian alien flora, 22 taxa are new for the island, seven of which are new also for the Italian territory (Tab. 1). Moreover, with respect to the previous checklist (Bacchetta et al., 2009), 44 new taxa from other authors' works are listed in Annex 1 (market with $\left.{ }^{* *}\right), 10$ of which were already reported in Podda et al. (2010).

Of the 541 taxa, 84 are doubtfully native in Sardinia and, in comparison with the previous reports (Bacchetta et al., 2009; Podda et al., 2010), this group has increased 
16

Tab. 1. New taxa for the Sardinian alien flora

\begin{tabular}{|c|c|c|c|c|c|c|c|}
\hline $\mathrm{n}^{\circ}$ & Taxon & $\begin{array}{l}\text { Site/Location (place } \\
\text { name, municipality, } \\
\text { province) }\end{array}$ & $\begin{array}{l}\text { Coord. Geogr. } \\
\text { (datum } \\
\text { WGS 84) }\end{array}$ & Elevation & Habitat & $\begin{array}{c}\text { Thermotype and } \\
\text { ombrotype }\end{array}$ & Herbarium (CAG) \\
\hline 1 & $\begin{array}{l}\text { Antirrhinum } \\
\text { siculum Mill. }\end{array}$ & Monte Zara, Monastir (CA) & $\begin{array}{l}39^{\circ} 22^{\prime} 54.93^{\prime \prime} \mathrm{N} \\
09^{\circ} 3{ }^{\prime} 0.86^{\prime \prime} \mathrm{E}\end{array}$ & $105 \mathrm{~m}$ & Synanthropic & $\begin{array}{l}\text { Thermomedit. sup. } \\
\text { Dry inf. }\end{array}$ & $\begin{array}{l}\text { G. Orrù, G. De Martis } \\
\text { et B. Mulas, 12.V.2008 }\end{array}$ \\
\hline \multirow{2}{*}{2} & \multirow{2}{*}{$\begin{array}{l}\text { Asparagus setaceus } \\
\text { (Kunth) Jessop }\end{array}$} & $\begin{array}{c}\text { Centro abitato, } \\
\text { Gonnosfanadiga (VS) }\end{array}$ & $\begin{array}{l}39^{\circ} 29^{\prime} 45,40^{\prime \prime} \mathrm{N} \\
08^{\circ} 39^{\prime} 52,58^{\prime \prime} \mathrm{E}\end{array}$ & $180 \mathrm{~m}$ & Synanthropic & $\begin{array}{l}\text { Thermomedit. sup. } \\
\text { Dry sup. }\end{array}$ & F. Mascia, 12.IX.2011 \\
\hline & & $\begin{array}{c}\text { Centro abitato, San } \\
\text { Gavino Monreale (VS) }\end{array}$ & $\begin{array}{l}39^{\circ} 33^{\prime} 02,18^{\prime \prime} \mathrm{N} \\
08^{\circ} 47^{\prime} 57,11^{\prime \prime} \mathrm{E}\end{array}$ & $55 \mathrm{~m}$ & Synanthropic & $\begin{array}{l}\text { Thermomedit. sup. } \\
\text { Dry inf. }\end{array}$ & F. Mascia, 22.VIII.2011 \\
\hline \multirow{2}{*}{3} & \multirow{2}{*}{$\begin{array}{l}\text { Bidens aurea } \\
\text { (Ait.) Sherff. }\end{array}$} & Riu Cixerri, Siliqua (CA) & $\begin{array}{l}39^{\circ} 17^{\prime} 55,93^{\prime \prime} \mathrm{N} \\
08^{\circ} 48^{\prime} 26,26^{\prime \prime} \mathrm{E}\end{array}$ & $54 \mathrm{~m}$ & Synanthropic & $\begin{array}{l}\text { Thermomedit. sup. } \\
\text { Dry inf. }\end{array}$ & F. Mascia, 03.XI.2010 \\
\hline & & $\begin{array}{l}\text { Riu S. Giovanni, } \\
\text { Selàrgius (CA) }\end{array}$ & $\begin{array}{l}39^{\circ} 15^{\prime} 45,24 ” \mathrm{~N} \\
09^{\circ} 9^{\prime} 51,45^{\prime \prime} \mathrm{E}\end{array}$ & $14 \mathrm{~m}$ & Synanthropic & $\begin{array}{l}\text { Thermomedit. sup. } \\
\text { Dry inf. }\end{array}$ & F. Mascia, 16.IX.2011 \\
\hline \multirow{2}{*}{4} & \multirow{2}{*}{$\begin{array}{l}\text { Catharanthus roseus } \\
\text { (L.) G. Don }\end{array}$} & $\begin{array}{l}\text { Centro abitato, } \\
\text { Oristano (OR) }\end{array}$ & $\begin{array}{l}39^{\circ} 54^{\prime} 17,04^{\prime \prime} \mathrm{N} \\
08^{\circ} 35^{\prime} 23,05^{\prime \prime} \mathrm{E}\end{array}$ & $10 \mathrm{~m}$ & Synanthropic & $\begin{array}{l}\text { Thermomedit. sup. } \\
\text { Dry inf. }\end{array}$ & F. Mascia, 05.VI.2011 \\
\hline & & Centro abitato, Villasor (CA) & $\begin{array}{l}39^{\circ} 22^{\prime} 49,90^{\prime \prime} \mathrm{N} \\
08^{\circ} 5610,31^{\prime \prime} \mathrm{E}\end{array}$ & $20-25 \mathrm{~m}$ & Synanthropic & $\begin{array}{l}\text { Thermomedit. sup. } \\
\text { Dry sup. }\end{array}$ & F. Mascia, 20.V.2011 \\
\hline 5 & Datura wrightii Regel & $\begin{array}{c}\text { Zona Cimitero, } \\
\text { Villasimius (CA) }\end{array}$ & $\begin{array}{l}39^{\circ} 08^{\prime} 07,38^{\prime \prime} \mathrm{N} \\
09^{\circ} 31^{\prime} 22,55^{\prime \prime} \mathrm{E}\end{array}$ & $20 \mathrm{~m}$ & Synanthropic & $\begin{array}{l}\text { Thermomedit. sup. } \\
\text { Dry inf. }\end{array}$ & $\begin{array}{c}\text { V. Lazzeri, L. } \\
\text { Podda, 31.V.2012 }\end{array}$ \\
\hline 6 & $\begin{array}{l}{ }^{*} \text { Grindelia } \\
\text { robusta Nutt. }\end{array}$ & $\begin{array}{l}\text { Marina di Orosei, } \\
\text { Orosei (NU) }\end{array}$ & $\begin{array}{c}40^{\circ} 22^{\prime} 28,46^{\prime \prime} \mathrm{N} \\
09^{\circ} 43^{\prime} 7,35^{\prime \prime} \mathrm{E}\end{array}$ & $0,5 \mathrm{~m}$ & Agricultural & $\begin{array}{l}\text { Thermomedit. sup. } \\
\text { Dry sup. }\end{array}$ & $\begin{array}{l}\text { G. Bacchetta, } \\
\text { 27.XII. } 2012\end{array}$ \\
\hline 7 & $\begin{array}{l}\text { Impatiens balfourii } \\
\text { Hook. f. }\end{array}$ & Sa 'uca manna, Sadali (NU) & $\begin{array}{l}39^{\circ} 49^{\prime} 05,94^{\prime \prime} \mathrm{N} \\
09^{\circ} 1641,27^{\prime \prime} \mathrm{E}\end{array}$ & $708 \mathrm{~m}$ & Synanthropic & $\begin{array}{l}\text { Mesomedit. sup. } \\
\text { Subhumid sup. }\end{array}$ & F. Mascia, 28.VIII.2011 \\
\hline 8 & $\begin{array}{l}\text { *Ipomoea cairica } \\
\text { (L.) Sweet }\end{array}$ & Cruxi ‘e ponti, Samassi (VS) & $\begin{array}{l}39^{\circ} 29^{\prime} 9,64 " \mathrm{~N} \\
08^{\circ} 54^{\prime} 17,45^{\prime \prime} \mathrm{E}\end{array}$ & $54 \mathrm{~m}$ & Synanthropic & $\begin{array}{l}\text { Thermomedit. sup. } \\
\text { Dry sup. }\end{array}$ & F. Mascia, 20.V.2011 \\
\hline \multirow{2}{*}{9} & \multirow{2}{*}{$\begin{array}{c}\text { *Jaborosa } \\
\text { integrifolia Lam. }\end{array}$} & Argiolas, Siliqua (CA) & $\begin{array}{l}39^{\circ} 17^{\prime} 57,52^{\prime \prime} \mathrm{N} \\
08^{\circ} 49^{\prime} 01,94^{\prime \prime} \mathrm{E}\end{array}$ & $50 \mathrm{~m}$ & Synanthropic & $\begin{array}{l}\text { Thermomedit. sup. } \\
\text { Dry inf. }\end{array}$ & F. Mascia, 26.IX.2011 \\
\hline & & $\begin{array}{c}\text { Is Locis, } \\
\text { San Giovanni Suèrgiu (CI) }\end{array}$ & $\begin{array}{l}39^{\circ} 07^{\prime} 20,61^{\prime \prime} \mathrm{N} \\
08^{\circ} 31^{\prime} 16,75^{\prime \prime} \mathrm{E}\end{array}$ & $21 \mathrm{~m}$ & Synanthropic & $\begin{array}{l}\text { Thermomedit. sup. } \\
\text { Dry inf. }\end{array}$ & F. Mascia, 26.IX.2011 \\
\hline 10 & $\begin{array}{c}\text { *Kalanchoë } \times \\
\text { houghtonii D.B. Ward }\end{array}$ & S. Elia, Cagliari (CA) & $\begin{array}{l}39^{\circ} 11^{\prime} 11,06 ” \mathrm{~N} \\
09^{\circ} 09^{\prime} 12,82^{\prime \prime} \mathrm{E}\end{array}$ & $8 \mathrm{~m}$ & Synanthropic & $\begin{array}{l}\text { Thermomedit. sup. } \\
\text { Dry inf. }\end{array}$ & $\begin{array}{l}\text { V. Lazzeri, L. Podda, } \\
\text { 10.VI.2012 }\end{array}$ \\
\hline 11 & Lathyrus odoratus L. & Is buronàrgius, Elmas (CA) & $\begin{array}{l}39^{\circ} 15^{\prime} 09,39^{\prime \prime} \mathrm{N} \\
09^{\circ} 04^{\prime} 02,24^{\prime \prime} \mathrm{E}\end{array}$ & $11 \mathrm{~m}$ & Synanthropic & $\begin{array}{l}\text { Thermomedit. sup. } \\
\text { Dry inf. }\end{array}$ & F. Mascia, 28.IV.2012 \\
\hline 12 & $\begin{array}{c}\text { Myoporum } \\
\text { insulare } \mathrm{R} . \mathrm{Br} \text {. }\end{array}$ & Timiama, Villasimius (CA) & $\begin{array}{l}39^{\circ} 07^{\prime} 08,28^{\prime \prime} \mathrm{N} \\
09^{\circ} 31^{\prime} 13,55^{\prime \prime} \mathrm{E}\end{array}$ & $2 \mathrm{~m}$ & Coastal & $\begin{array}{l}\text { Thermomedit. sup. } \\
\text { Dry inf. }\end{array}$ & $\begin{array}{c}\text { V. Lazzeri, L. } \\
\text { Podda, 31.V.2012 }\end{array}$ \\
\hline 13 & Nigella sativa L. & Sassu, Arborea (OR) & $\begin{array}{l}39^{\circ} 49^{\prime} 33,31^{\prime \prime} \mathrm{N} \\
08^{\circ} 35^{\prime} 42,55^{\prime \prime} \mathrm{E}\end{array}$ & $0 \mathrm{~m}$ & Agricultural & $\begin{array}{l}\text { Thermomedit. sup. } \\
\text { Dry sup. }\end{array}$ & F. Mascia, 05.VI.2011 \\
\hline 14 & ${ }^{*}$ Oxalis carnosa Molina & Centro abitato, Elmas (CA) & $\begin{array}{l}39^{\circ} 15^{\prime} 56,92^{\prime \prime} \mathrm{N} \\
09^{\circ} 02^{\prime} 41,82^{\prime \prime} \mathrm{E}\end{array}$ & $2 \mathrm{~m}$ & Synanthropic & $\begin{array}{l}\text { Thermomedit. sup. } \\
\text { Dry inf. }\end{array}$ & F. Mascia, 11.III.2011 \\
\hline 15 & $\begin{array}{l}\text { Paulownia tomentosa } \\
\text { (Thunb.) Steud. }\end{array}$ & Casa Maxia, Serramanna (VS) & $\begin{array}{l}39^{\circ} 24^{\prime} 59,44^{\prime \prime} \mathrm{N} \\
08^{\circ} 53^{\prime} 54,00^{\prime \prime} \mathrm{E}\end{array}$ & $36 \mathrm{~m}$ & Agricultural & $\begin{array}{l}\text { Thermomedit. sup. } \\
\text { Dry sup. }\end{array}$ & F. Mascia, 20.V.2011 \\
\hline 16 & $\begin{array}{l}\text { Populus deltoides } \\
\text { Marshall }\end{array}$ & Rio Pelau, Cardedu, (OG) & $\begin{array}{l}39^{\circ} 47^{\prime} 10.19^{\prime \prime} \mathrm{N} \\
09^{\circ} 40^{\prime} 5.21 " \mathrm{E}\end{array}$ & 3 & Riparian & $\begin{array}{l}\text { Thermomedit. sup. } \\
\text { Dry sup. }\end{array}$ & $\begin{array}{l}\text { G. Bacchetta, } \\
\text { 23.VI.2012 }\end{array}$ \\
\hline \multirow{2}{*}{17} & \multirow{2}{*}{$\begin{array}{l}\text { Sempervivum } \\
\text { tectorum } \mathrm{L} \text {. }\end{array}$} & Centro abitato, Sadali (NU) & $\begin{array}{l}39^{\circ} 49^{\prime} 07,22^{\prime \prime} \mathrm{N} \\
09^{\circ} 1639,75^{\prime \prime} \mathrm{E}\end{array}$ & $712 \mathrm{~m}$ & Synanthropic & $\begin{array}{l}\text { Mesomedit. sup. } \\
\text { Subhumid. sup. }\end{array}$ & F. Mascia, 28.VIII.2011 \\
\hline & & Centro abitato, Seui (OG) & $\begin{array}{l}39^{\circ} 50^{\prime} 22,48^{\prime \prime} \mathrm{N} \\
09^{\circ} 19^{\prime} 14,20^{\prime \prime} \mathrm{E}\end{array}$ & $770 \mathrm{~m}$ & Synanthropic & $\begin{array}{l}\text { Mesomedit. sup. } \\
\text { Subhumid. sup. }\end{array}$ & F. Mascia, 27.III.2011 \\
\hline 18 & $\begin{array}{c}\text { *Sparaxis tricolor } \\
\text { (Schneev.) Ker Gawl. }\end{array}$ & Sa Masa, Gonnesa (CI) & $\begin{array}{l}39^{\circ} 16^{\prime} 32.40^{\prime \prime} \mathrm{N} \\
08^{\circ} 27^{\prime} 25.22^{\prime \prime} \mathrm{E}\end{array}$ & 13 & Wetlands & $\begin{array}{l}\text { Thermomedit. sup. } \\
\text { Dry sup. }\end{array}$ & $\begin{array}{l}\text { G. Bacchetta } \\
\text { 09.IV.2011 }\end{array}$ \\
\hline 19 & $\begin{array}{l}\text { Stenotaphrum } \\
\text { secundatum } \\
\text { (Walter) Kuntze }\end{array}$ & Monte Urpinu, Cagliari (CA) & $\begin{array}{l}39^{\circ} 13^{\prime} 0,49^{\prime \prime} \mathrm{N} \\
09^{\circ} 08^{\prime} 6,48^{\prime \prime} \mathrm{E}\end{array}$ & $50 \mathrm{~m}$ & Synanthropic & $\begin{array}{l}\text { Thermomedit. sup. } \\
\text { Dry inf. }\end{array}$ & $\begin{array}{l}\text { G. Bacchetta, F. Mascia, } \\
\text { L. Podda, 13.IX.2010 }\end{array}$ \\
\hline \multirow{2}{*}{20} & \multirow{2}{*}{$\begin{array}{c}\text { *Talinum paniculatum } \\
\text { Gaertn. }\end{array}$} & Monte Urpinu, Cagliari (CA) & $\begin{array}{l}39^{\circ} 13^{\prime} 0,49^{\prime \prime} \mathrm{N} \\
09^{\circ} 08^{\prime} 6,48^{\prime \prime} \mathrm{E}\end{array}$ & $50 \mathrm{~m}$ & Synanthropic & $\begin{array}{l}\text { Thermomedit. sup. } \\
\text { Dry inf. }\end{array}$ & $\begin{array}{c}\text { G. Bacchetta, F. Mascia, } \\
\text { L. Podda, 16.X.2011 }\end{array}$ \\
\hline & & $\begin{array}{c}\text { Centro abitato, } \\
\text { Vallermosa (CA) }\end{array}$ & $\begin{array}{l}39^{\circ} 21^{\prime} 54,46^{\prime \prime} \mathrm{N} \\
08^{\circ} 47^{\prime} 36,56^{\prime \prime} \mathrm{E}\end{array}$ & $75 \mathrm{~m}$ & Synanthropic & $\begin{array}{l}\text { Termomedit. sup. } \\
\text { Dry sup. }\end{array}$ & F. Mascia, 07.VI.2011 \\
\hline 21 & $\begin{array}{l}\text { Taxodium distichum } \\
\text { (L.) Richt. }\end{array}$ & $\begin{array}{l}\text { Lago piccolo, Poggio } \\
\text { dei Pini (CA) }\end{array}$ & $\begin{array}{l}39^{\circ} 8^{\prime} 48.56^{\prime \prime} \mathrm{N} \\
08^{\circ} 58^{\prime} 41.90^{\prime \prime} \mathrm{E}\end{array}$ & $57 \mathrm{~m}$ & Wetlands & $\begin{array}{l}\text { Thermomedit. sup. } \\
\text { Dry sup. }\end{array}$ & $\begin{array}{l}\text { G. Bacchetta, } \\
\text { 03.VI.2011 }\end{array}$ \\
\hline 22 & $\begin{array}{l}\text { Tristagma uniflorum } \\
\text { (Lindl.) Traub }\end{array}$ & Centro abitato, Sestu (CA) & $\begin{array}{c}39^{\circ} 17^{\prime} 38,21 " \mathrm{~N} \\
09^{\circ} 5^{\prime} 48,84^{\prime \prime} \mathrm{E}\end{array}$ & $45 \mathrm{~m}$ & Synanthropic & $\begin{array}{l}\text { Thermomedit. sup. } \\
\text { Dry inf. }\end{array}$ & F. Mascia, 13.III.2010 \\
\hline
\end{tabular}

Note: ${ }^{*}$ indicates that the taxon is new for the Italian flora 
from 20 to 84 since 32 are new for the flora, 10 were already reported as doubtful in Podda et al. (2010) and 42 are now considered doubtful (Annex 1).

The diffusion status of 44 naturalized taxa has changed since 16 are now considered invasive and 28 casual while, among six taxa previously considered casual, four are now listed as naturalized and one as invasive. Moreover, the status of nine taxa has changed from invasive to naturalized in six cases and to casual in other three cases, while six doubtful taxa are now considered naturalized in three cases and casual in the remaining three cases.

In this update, $66 \%$ (previously 62\%) of the Sardinian alien flora is represented by neophytes (301 taxa) while 156 taxa, corresponding to the $34 \%$ (previously $38 \%$ ), are archaeophytes (Fig. 1). Concerning the 22 new taxa (Tab. 1), 18 currently must be considered not more than barely casual whilst the other five can come within the category of the naturalized but without showing any invasiveness now. However, among them, at least six taxa are considered capable of invasiveness in Europe: Bidens aurea (Gassó et al., 2012), Datura wrightii (Verloove, 2008), Impatiens balfourii (Schmitz and Dericks, 2010), Kalanchoe $\times$ houghtonii (Guillot Ortiz, 2005, 2008; Guillot Ortiz et al., 2009), Paulownia tomentosa (Essl, 2007), Stenotaphrum secundatum (Ferrer Merino and Donat, 2011) and one, Ipomoea cairica, is reported as invasive at least outside Europe (Huang et al., 2009; Weber et al., 2008).

Of the 457 alien taxa (doubtuful excluded), 58 (13\%) are invasive, 160 (35\%) are naturalized and 239 (52\%) are casual. Among the neophytes the number of invasive taxa is quite high and has increased from 50 to 54 (11\% against 18\%) in comparison with the previous data, while $95(32 \%)$ are naturalized and $152(50 \%)$ are casual. Differently, the archaeophytes still show very little invasiveness since only four taxa (2\%) (Fig. 1), Acanthus mollis ssp. mollis, Arundo donax, Ricinus communis and Sorghum halepense can be considered as invasive, while 65 (42\%) are naturalized and $87(56 \%)$ casual.

Alien taxa found in Sardinia belong to 87 families, among which the most represented are Fabaceae ( 45 taxa) followed by Poaceae (33) and Asteraceae (31) (Fig.

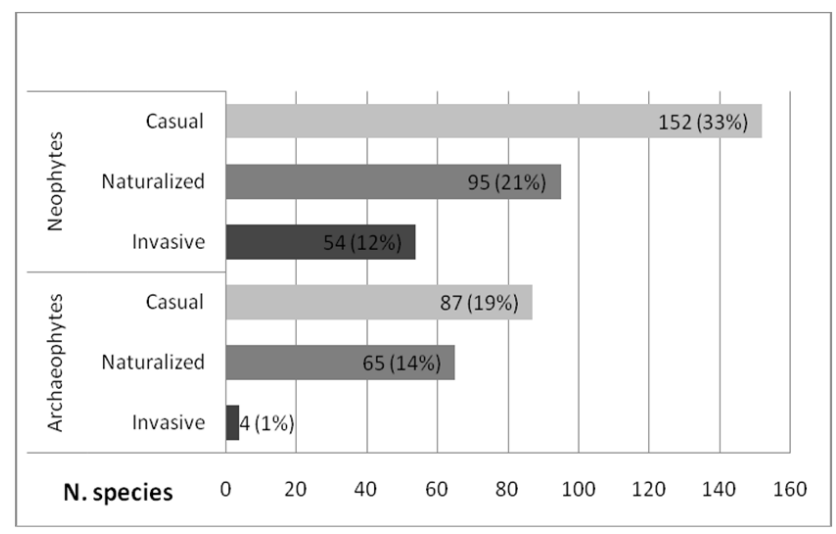

Fig. 1. Number of taxa per diffusion status among neophytes and archaeophytes
2). These families have a well known weedy tendency and are aften among the most representative alien plants in the European territory (Daehler, 1998; Pyšek, 1998; Pyšek et al., 2009). Notwithstanding, non-Mediterranean families such as Aizoaceae and Cactaceae display the highest number of taxa that can be considered invasive in Sardinia, as expected, due to their absolute lack of archaeophytes (Fig. 3). Making a comparison with the native flora of Sardinia, it appears that important families, in terms of number of taxa, such as Apiaceae, Caryophyllaceae, Orchidaceae, Plumbaginaceae and Ranunculaceae are scarcely represented or totally absent among the alien flora (Annex 1).

The biological spectrum (Fig. 4) reveals a situation where phanerophytes (42\%) and terophytes (28\%) are dominant among the Sardinian alien flora while other life forms such as hemicryptophytes (11\%), geophytes (10\%), camephytes (7\%) and hydrophytes (2\%) are clearly less representative. These data suggest that the woody habit is a major factor for land colonization in the Mediterranean as previously reported (Blondel and Aronson, 1999) and particularly in Sardinia, even if the annual component is likewise important. Indeed, even if not matching with the biological spectrum of the native Sardinian flora (Bocchieri, 1995), this is consistent with what previously observed by other authors for Sardinia and other islands characterized by similar Mediterranean climates (Lloret et al., 2004) where the extended dry season appears as one of the main features of selection. In this situation, alien phanerophytes and therophytes occupy different niches and base their success in colonizing the land through different ways to face water scarcity, the first group through their architecture while the second just avoiding the dry season (Allen, 2001). Moreover, it is undoubtful that another important previous factor that affects the present biological spectrum involves the direct human intervention in selecting which species to introduce in the island, and this is particularly true with woody plants for ornamental or forestry uses.

Concerning the geographical origin of the alien taxa in Sardinia (Fig. 5) a marked dominance of the American group can be observed (33\%) while Mediterranean (15\%) or European s. l. taxa (9\%) represent only a minority thus

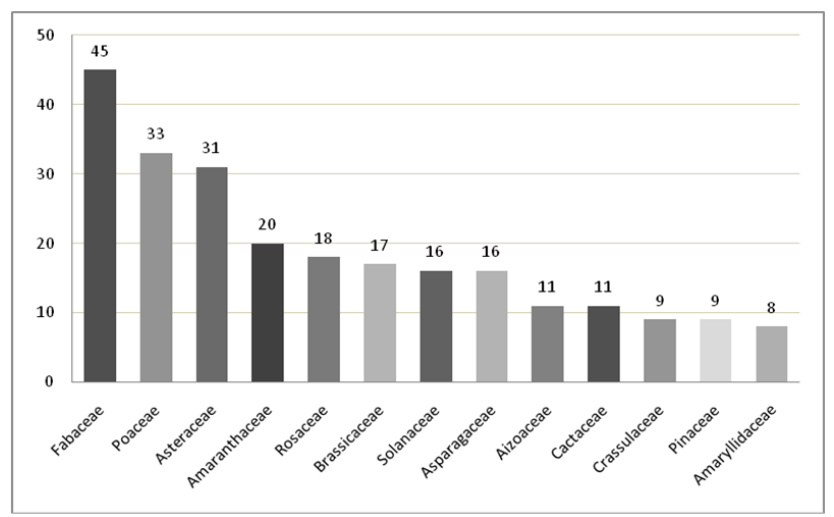

Fig. 2. Number of taxa in the most representative families in the Sardinian alien flora 
18

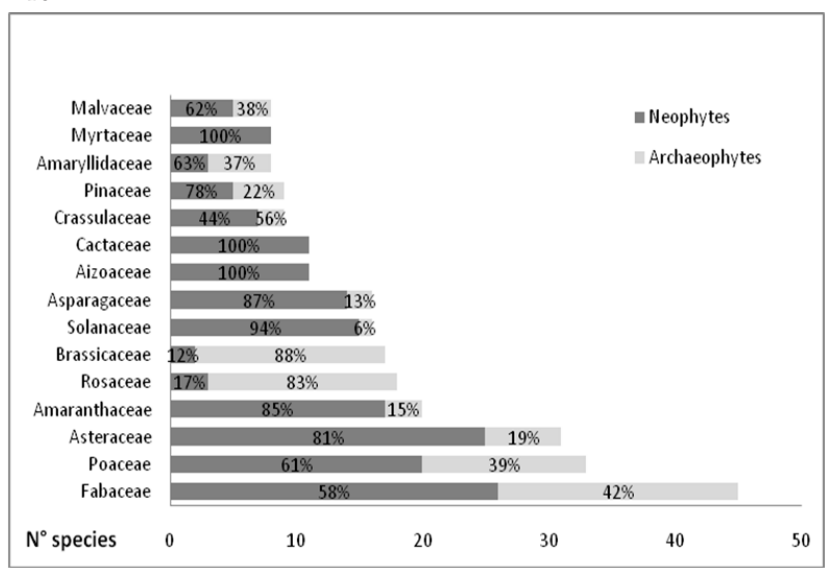

Fig. 3. Number of taxa and percentage repartition among neophytes and archaeophytes per family. Only the 15 most representative families are represented

suggesting that in most of the cases the introduction may have been intentional or involuntary but often through human action.

Regarding the kind of habitat where alien taxa have been found in Sardinia (Fig. 6), it appears clear that areas that have been severely modified by human activities such as synantropic (36\%) and agricultural areas $(23 \%)$ are more prone to alien flora colonization. In contrast, more natural habitats such as matorrals and woodlands (respectively $3 \%$ and $7 \%$ ) seem to show an enhanced resistance, in terms of number of taxa, to alien plant invasions mainly due to a higher competitiveness of native woody species and to the scarcity of free spaces to be occupied. Instead, wetlands (12\%), coastal (10\%) and riparian habitats (9\%) show an intermediate number of alien colonizing taxa and this data might be related to the more restrictive environmental conditions. However, although these latest habitats host a smaller number of alien taxa, it must be pointed out that they are the most susceptible to deterioration due to human pressure and/or alien taxa establishment (Bacchetta et al., 2008; Blondel and Médail, 2009; Mascia et al., 2009; Schnitzler et al., 2007; Zedler and Kercher, 2004). Moreover, a seriously large extent of the Sardinian coasts -especially sandy shores- is affected by the worrying

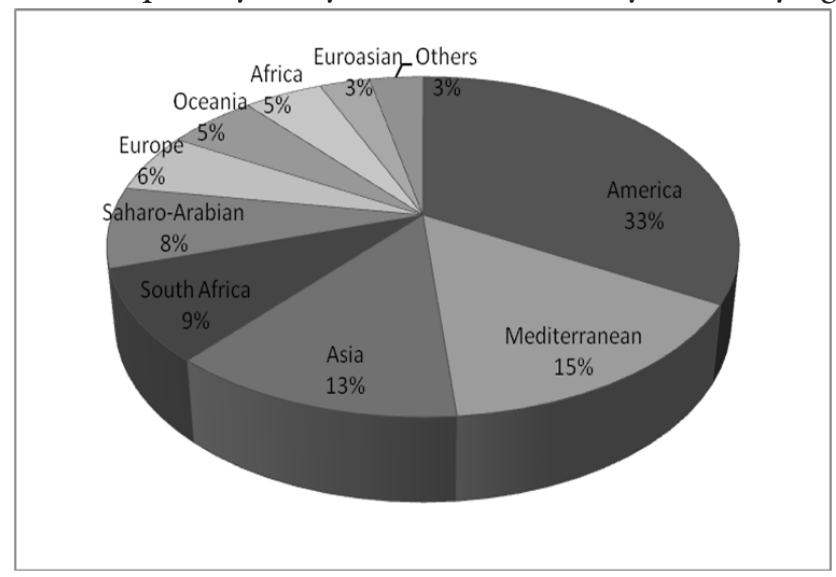

Fig. 5. Geographical origin of the Sardinian alien flora

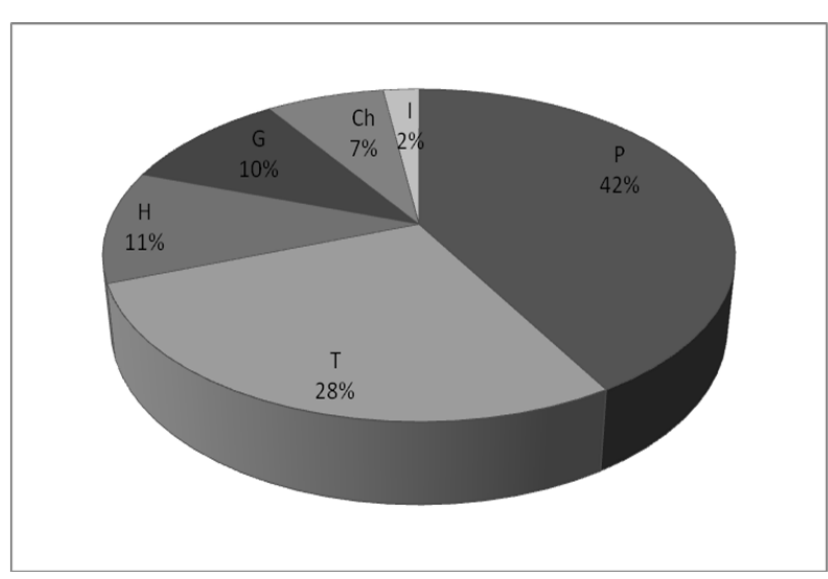

Fig. 4. Biological spectrum of the Sardinian alien flora. Phanerophytes $(\mathrm{P})$, chamaephytes $(\mathrm{Ch})$, hemicryptophytes $(\mathrm{H})$, geophytes $(\mathrm{G})$, hydrophytes $(\mathrm{I})$, therophytes $(\mathrm{T})$

presence of two of the most invasive pests, Acacia saligna and Carpobrotus sp. pl. and, together with wetlands, where Azolla filiculoides, Cortaderia selloana and Eichhornia crassipes constitute a not less severe threat, among all the examined habitats show the highest percentage of invasive taxa in proportion to the whole alien flora present in these two habitats (Fig. 7). This means that, despite the relatively low number of alien taxa, coasts and wetlands are remarkably far more endangered by alien plants than any other habitats, likely due to their intrinsic homogeneity and relatively high similarity with original habitats of the invaders (Lambdon et al., 2008b), especially in the cases where natural sites are stressed by human activities (Shea and Chesson, 2002).

In reference to the introduction pathways (Fig. 8), as already suggested by the data regarding the biological form and the geographical origin and in accordance with the previously discovered by other authors (Hulme et al., 2008a; Lambdon et al., 2008b; Pyšek et al., 2009), most of the alien taxa found in Sardinia are supposed to be introduced through human activities and, in most cases voluntarily (79\%). Correspondingly, the analysis of the whole alien flora has revealed that cultivation for ornamental purposes is the main source of alien taxa in Sardinia (45\%)

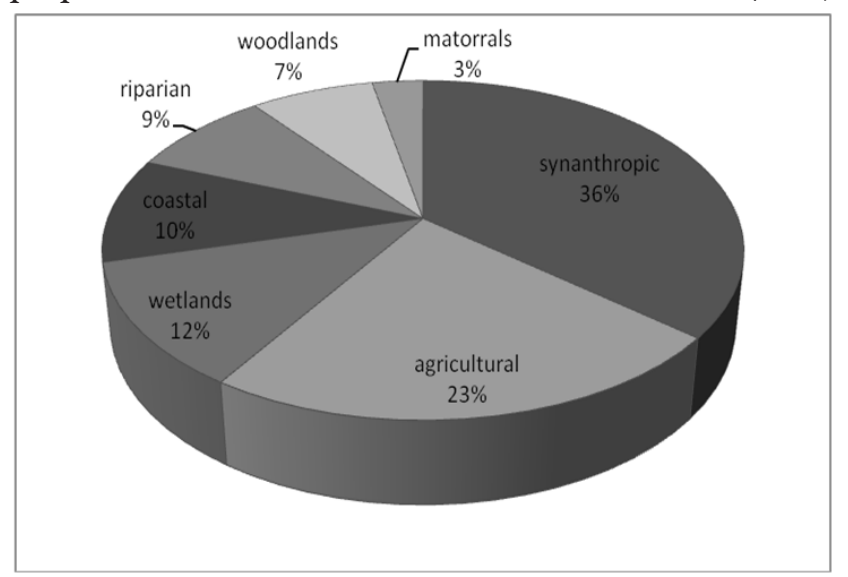

Fig. 6. Distribution of the Sardinian alien flora among different habitats 


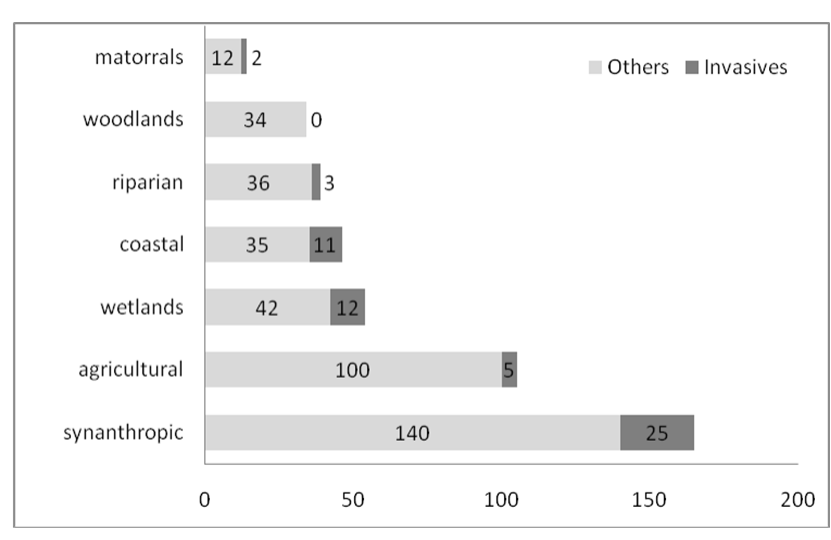

Fig. 7. Alien (light grey) and invasive (dark grey) flora of sensitive habitats

followed by crops (25\%), weeds (14\%), forestry (9\%) and accidental elements (7\%). In relation with what reported by Lambdon et al. (2008b), the ornamental group displays the highest stress tolerance suggesting how this feature is a key factor for success in Mediterranean scenarios. In this regard, stressing environments such as sandy shores may be easily and extensively colonized by strong invaders. Notwithstanding, it is still possible that the overall number of taxa due to accidental introductions in a certain area could be underestimated for the difficulty in finding certain proofs that validate these data (Mack et al, 2000).

In the end, concerning the number of alien plants in relation to the extent of the studied area (number of taxal log area), the total Sardinian alien taxa have shown a density of 53,6 with a fair increase from the last report $(46,8$; Bacchetta et al., 2009) but still markedly lower than that of the whole Italian territory $(81,1$; Celesti-Grapow et al., 2010). Instead, only the total neophytes density has slightly increased since 2010 from 28.8 to 29.8 while all other densities (total naturalized plus invasive, total neophytes, total archaeophytes, naturalized plus invasive neophytes and naturalized plus invasive archaeophytes) have shown a bold decrease.

\section{Conclusions}

The issues related to alien plants and their possible management have been taken into account only recently, especially from an institutional and organized point of view. Despite the lack of a specific European legislation, what was stated during the 1992 Convention on Biological Diversity in its $8^{\text {th }}$ Article implies that the knowledgde of the status and the taxonomy of invasive or potentially threatening taxa should be the most comprehensive possible by those at the forefront of biodiversity conservation. In this perspective, the data here presented constitute the necessary update of the Sardinian alien flora checklist and, on this basis, the picture that emerges is characterized by the presence of a relatively high number of taxa of concern for the examined territory, including those that constitute a severe threat for ecosystems integrity. In detail, it is worth
19

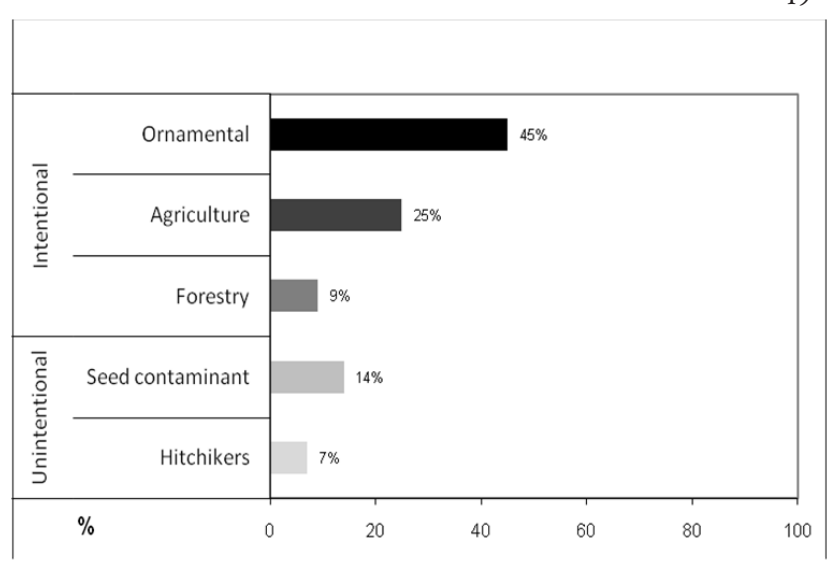

Fig. 8. Introduction pathways of the Sardinian alien flora

noting that Sardinian alien flora shows certain dominances of neophytes over archaeophytes, of phanerophytes over other biological forms, of casuals over estabilished taxa, of the American element over other geographical origins and the likely intentional introduction over accidental one. Notwithstanding, among casuals, a fair component of potentially invasive taxa is present and, given the overexploitation which has undergone for a long time in Sardinia and as insularity seems to be a positive factor for the spreading of aliens (Sala et al., 2000), it is desirable to keep watch over these taxa at present, when they are still not widespread.

\section{Aknowledgements}

This study has received a RAS research grant cofinanced by POR Sardegna FSE 2007-2013 L.R.7/2007 "Promozione della ricerca scientifica e dell'innovazione tecnologica in Sardegna". Authors want to thank Provincia di Cagliari for financing the research activity.

\section{References}

Allen HD (2001). Mediterranean ecogeography. Pearson Education Limited. Edimburgh.

Bacchetta G, Mascia F, Mayoral García-Berlanga O, Podda L (2008). Preliminary data on the alien flora of the wetlands of Sardinia (Italy). Mem Soc Ital Sci Nat Mus Civ Stor Nat Milano 36:41 (in Italian).

Bacchetta G, Mayoral García-Berlanga O, Podda L (2009). Checklist of the exotic flora of Sardinia (Italy). Flora Montiberica 41(1):35-61 (in Spanish).

Blondel J, Aronson J (1999). Biology and Wildlife of the Mediterranean Region. Oxford University Press, Oxford, UK.

Blondel J, Médail F (2009). Biodiversity and conservation, 615650 p. In: Woodward JC (Ed.). The physical geography of the Mediterranean. Oxford University Press, Oxford.

Bocchieri E (1995). Knowledge and the state of conservation of the flora in Sardinia. Ecol Medit 21(1-2):71-81 (in French).

Carlton JT (1996). Biological invasions and cryptogenic species. 
20 Ecology 77:1653-1655.

Celesti-Grapow L, Pretto F, Brundu G, Carli E, Blasi C (Eds.) (2009). Plant invasion in Italy. An overview. Palombi \& Partner, Rome.

Celesti-Grapow L, Pretto F, Carli E, Blasi C (Eds.) (2010). Nonnative and invasive vascular flora of the regions of Italy. Casa Editrice Università La Sapienza, Roma (in Italian).

Chase MW, Reveal JL (2009). A phylogenetic classification of the land plants to accompany APG III. Bot J Linnean Soc 161:122-127.

Conti F, Abbate G, Alessandrini A, Blasi C (Eds.) (2005). An Annoted Checklist of the Italian Vascular Flora. Palombi Editori, Roma.

Conti F, Alessandrini A, Bacchetta G, Banfi E, Barberis G, Bartolucci F, Bernardo L, Bonacquisti S, Bouvet D, Bovio M, Brusa G, Del Guacchio E, Foggi B, Frattini S, Galasso G, Gallo L, Gangale C, Gottschlich G, Grünanger P, Gubellini L, Iiriti G, Lucarini D, Marchetti D, Moraldo B, Peruzzi L, Poldini L, Prosser F, Raffaelli M, Santangelo A, Scassellati E, Scortegagna S, Selvi F, Soldano A, Tinti D, Ubaldi D, Uzunov D, Vidali M (2007). Additions to the checklist of the Italian vascular flora. Natura Vicentina 10:5-74 (in Italian).

Christenhusz MJM, Zhang XC, Schneider H (2011a). A linear sequence of extant families and genera of lycophytes and ferns. Phytotaxa 19:7-54.

Christenhusz MJM, Reveal JL, Farjon A, Gardner MF, Mill RR, Chase MW (2011b). A new classification and linear sequence of extant gymnosperms. Phytotaxa 19:55-70.

Daehler CC (1998). The taxonomic distribution of invasive angiosperm plants: ecological insights and comparison to agricultural weeds. Biol Conserv 84:167-180.

Essl F (2007). From ornamental to detrimental? The incipient invasion of Central Europe by Paulownia tomentosa. Preslia 79:377-389.

Euro+Med (2006-onwards). Euro+Med PlantBase - the information resource for Euro-Mediterranean plant diversity. Published on the website http://ww2.bgbm.org/ EuroPlusMed/ [accessed $15^{\text {th }}$ September 2012].

Ferrer Merino F, Donat PM (2011). Invasive plants in the coastal vegetal communities in Valencia (Spain). Not Bot Horti Agrobo 39(1):9-17.

Gassó N, Thuiller W, PinoJ, Vilà M(2012). Potential distribution range of invasive plant species in Spain. NeoBiota 12:25-40.

Guillot Ortiz D (2005). Kalanchoe x bybrida Hort., a new invasive taxon in the Valencian Community. Lagascalia 25:176-177 (in Spanish).

Guillot Ortiz D (2008). A new invasive taxon in the Balearic flora, Kalanchoe x houghtonii D.B. Ward. Acta Bot Barc 51:129-130 (in Spanish).

Guillot Ortiz D, Laguna Lumbreras E, Rosselló Picornell JA (2009). The family Crassulaceae in the Valencian alien flora. Monog Rev Bouteloua 4:1-106 (in Spanish).
Huang QQ, Wu JM, Bai YY, Zhou L, Wang GX (2009). Identifying the most noxious invasive plants in China: role of geographical origin, life form and means of introduction. Biodivers Conserv 18:305-316.

Holub J, Jirásek V (1967). For unification of terminology in phytogeography. Folia Geobot Phytotax 2:69-113 (in German).

Hulme PE, Bacher S, Kenis M, Klotz S, Kühn I, Minchin D, Nentwig W, Olenin S, Panov V, Pergl J, Pyšek P, Roque A, Sol D, Solarz W, Vilà M (2008a). Grasping at the routes of biological invasions: a framework for integrating pathways into policy. J Appl Ecol 45:403-414.

Hulme PE, Brundu G, Camarda I, Dalias P, Lambdon P, Lloret F, MéDail F, Moragues E, Suehs C, Traveset A, Troumbis A, Vilà M (2008b). Assessing the risks to Mediterranean islands ecosystems from alien plant introductions, 39-56 p. In: Tokarska-Guzik B et al. (Eds.). Plant invasions: human perception, ecological impacts and management. Backhuys Publishers, Leiden.

Jeanmonod D, Schlüssel A, Gamisans J (2011). Status and trends in the alien flora of Corsica. OEPP/EPPO Bulletin 41:85-99.

Lambdon PW, Pyšek P, Basnou C, Hejda M, Ariannoutsou M, Essl F, Jarošík V, Pergl J, Winter M, Anastasiu P, Andriopoulos P, Bazos I, Brundu G, Celesti-Grapow L, Chassot P, Delipetrou P, Josefsson M, Kark S, Klotz S, Kokkoris Y, Kühn I, Marchante H, Perglová I, Pino J, Vilà M, Zikos A, Roy D, Hulme P (2008a). Alien flora of Europe: species diversity, temporal trends, geographical patterns and research needs. Preslia 80:101-149.

Lambdon PW, Lloret F, Hulme PE (2008b). Do alien plants on Mediterranean islands tend to invade different niches from native species? Biol Invasions 10:703-716.

Lloret F, Médail F, Brundu G, Hulme PE (2004). Local and regional abundance of exotic plant species on Mediterranean islands: are species traits important? Global Ecol Biogeogr 13:37-45.

Mack R, Simberloff, D, Lonsdale, W, Evans, H, Clout, M, Bazzaz, F (2000). Biotic invasions. Causes, epidemiology, global consequences and control. Ecol Appl 10:689-710.

Mascia F, Podda L, Bacchetta G (2009). Alien flora in temporary ponds of Sardinia: preliminary data on invasive species and threatened habitats. Proc Int Conf Medit Temp Ponds Minorca 423.

Miller C, Kettunen M, Shine C (2006). Scope options for $\mathrm{EU}$ action on invasive alien species (IAS). Final report for the European Commission. Institute for European Environmental Policy (IEEP), Brussels.

Moragues Botey E, Rita Larrucea J (2005). Introduced plants in the Balearic Islands. Documents tècnics de conservaciò, IIa època, núm. 11. Govern de les Illes Balears. Conselleria de Medi Ambient, Palma (in Catalan).

Natali A, Jeanmonod D (1996). Analytical flora of introduced plants in Corsica, 1-211 p. In: Jeanmonod D, Burdet HM 
(Eds.). Compléments au Prodrome de la Flore Corse. Annexe no 4. Conserv Jard bot Ville Genève, Genève (in French).

Pignatti S (1982). Flora of Italy 1-3. Edagricole, Bologna (in Italian).

Podda L, Fraga I, Arguimbau P, Mayoral García-Berlanga O, Mascia F, Bacchetta $G$ (2010). Comparison of alien vascular flora in continental islands: Sardinia (Italy) and Balearic Islands (Spain). An Jard Bot Madrid 67(2):157-176 (in Spanish).

Podda L, Fraga I, Arguimbau P, Mascia F, Mayoral O, Bacchetta $G$ (2011). Comparison of the invasive alien flora in continental islands: Sardinia (Italy) and Balearic Islands (Spain). Rend Fis Acc Lincei 22(1):31-45.

Pyšek P (1998). Is there a taxonomic pattern to plant invasions? Oikos 82:282-294.

Pyšek P, Sádlo J, Mandák B, Jarošík V (2003). Czech alien flora and a historical pattern of its formation: what came first to Central Europe? Oecologia 135:122-130.

Pyšek P, Richardson DM, Rejmánek M, Webster GL, Williamson M, Kirschner J (2004). Alien plants in checklist and floras: towards better communication between taxonomist and ecologists. Taxon 53(1):131-143.

Pyšek P, Richardson DM, Jarošík V (2006). Who cites who in the invasion zoo: insights from an analysis of the most highly cited papers in invasion ecology. Preslia 78:437-468.

Pyšek P, Lambdon PW, Arianoutsou M, Kühn I, Pino J, Winter M (2009). Alien vascular plants of Europe, 43-61 p. In: DAISIE. The Handbook of Alien Species in Europe. Invading Nature. Springer Series in Invasion Ecology Springer. Amsterdam.

Raunkiaer C (1934). The life forms of plants and statistical plant geography. Univ. Oxford, Oxford.

Richardson DM, Pyšek P, Rejmánek M, Barbour MG, Panetta FD, West CJ (2000). Naturalization and invasion of alien plants: concepts and definitions. Divers Distrib 6:93-107.

Richardson DM, Pyšek P (2006). Plant invasions: merging the concepts of species invasiveness and community invasibility. Prog Phys Geogr 30:409-431.

Sala OE, Chapin FS, Armesto JJ, Below E, Bloomfield J, Dirzo R., E Huber-Sanwald, Huenneke LF, Jackson RB, Kinzig A, Leemans R, Lodge DM, Mooney HA, Oesterheld M, Poff NLR, Sykes MT, Walker BH, Walker M, Wall DH (2000). Global biodiversity scenarios for the year 2100. Science 287:1770-1774.
Schnitzler A, Hale BW, Alsum EM (2007). Examining native and exotic species diversity in European riparian forests. Biol Conserv 138:146-156.

Sanz Elorza M, Dana Sánchez ED, Sobrino Vesperinas E (2004). Atlas of invasive alien plants in Spain. Ministero de Medio Ambiente, Madrid (in Spanish).

Shea K, Chesson P (2002). Community ecology theory as a framework for biologial invasions. Trends Ecol Evol 17:170176.

Schmitz U, Dericks G (2010). Spread of alien invasive Impatiens balfourii in Europe and its temperature, light and soil moisture demands. Flora 205:772-776.

Stevens PF (2001- onwards). Angiosperm Phylogeny Website. Version 9http://www.mobot.org/MOBOT/research/ APweb/ [accessed 15 ${ }^{\text {th }}$ September 2012].

The Plant List (2010). Version 1. Published on the website; http://www.theplantlist.org/ [accessed $15^{\text {th }}$ September 2012].

Tutin TG, Burges NA, Chater AO, Edmondson JR, Heywood VH, Moore DM, Valentine DH, Walters SM, Webb DA (1964-1980). Flora Europaea, 1-2-3-4-5. Cambridge University Press, Cambridge.

Verloove F (2008). Datura wrightii (Solanaceae), a neglected xenophyte, new to Spain. Bouteloua 4:37-40.

Viegi L (1993). Contribution to the knowledge of the biology of pests of crops in the north-west of Sardinia. I. Checklist of the exotic species of Sardinia. Boll Soc Sarda Sci Nat 29:131234 (in Italian).

Viegi L, Cela Renzoni G, Garbari F (1974). Alien flora of Italy. Lav Soc Ital Biogeogr 4:124-220 (in Italian).

Weber E, Sun SG, Li B (2008). Invasive alien plants in China: diversity and ecological insights. Biol Invasions 10:14111429.

Zedler JB, Kercher S (2004). Causes and consequences of invasive plants in wetlands: opportunities, opportunists, and outcomes. Crit Rev Plant Sci 23(5):431-452. 